\title{
Caregiver Burden and Psychoeducational Interventions in Alzheimer's Disease: A Review
}

\author{
$\begin{array}{llll}\text { N. Beinart } & \text { J. Weinman } & \text { D. Wade } & \text { R. Brady }\end{array}$ \\ ${ }^{\mathrm{a}}$ Institute of Psychiatry, Kings College London, and ${ }^{\mathrm{b}}$ Atlantis Healthcare, London, UK
}

\section{Key Words}

Alzheimer's disease $\cdot$ Caregiver burden • Caregivers • Carer stress • Care for the aged

\begin{abstract}
Background: Caring for a patient with Alzheimer's disease (AD) is associated with poor quality of life and deteriorating health for the caregiver. Methods: This comprehensive review was performed to investigate the current literature on caregiver burden, factors affecting caregiver burden and the effectiveness of different types of intervention. Results: Successful psychoeducational interventions for caregivers have included provision of information about $A D$, care planning, advice about patient management and the importance of self-care, skills training to aid patient management, stress management training, and problem-solving and decision-making guidance. Conclusion: Interventions that are individually tailored to the caregiver are particularly effective at reducing caregiver burden and should be further investigated. The use of effective pharmacological treatment for the improvement and/or stabilisation of AD symptoms in the patient is also likely to improve caregiver burden.

Copyright $\odot 2012$ S. Karger AG, Basel
\end{abstract}

\section{Introduction}

This review concerns the burden placed on caregivers of patients with dementia, particularly Alzheimer's disease (AD). AD is a chronic neurodegenerative disease that is characterised by impaired cognitive function, leading to deficits in a number of domains, including memory, language, judgement, decision-making, orientation and learning $[1,2]$. AD, the most common cause of dementia, accounts for approximately two-thirds of all cases in old- 
er adults and leads to significant changes in a person's daily life and activities [1]. The global prevalence of $\mathrm{AD}$ is currently estimated to be as high as 24 million and is predicted to more than double every 20 years through to 2040 [3].

$\mathrm{AD}$ is one of the most significant health, social and economic challenges of the 21st century. In the UK, 820,000 people have dementia, and two-thirds of them are cared for informally at home by a friend or relative [4]. Indeed, the contribution of informal caregivers in AD is considerable. In the United States, in 2010, nearly 15 million family members and other unpaid caregivers provided an estimated 17 billion hours of care to people with $\mathrm{AD}$ and other dementias, a contribution valued at more than USD 202 billion [5]. Caregivers are a crucial part of the overall care of patients with $\mathrm{AD}$, and their contribution should not be underestimated.

Definitions of caregiver burden vary in the literature. The definition proposed by George et al. [6] is widely accepted and has been used for the purpose of this review: caregiver burden is 'a perceived complex and multidimensional construct, which includes the physical, psychological or emotional, social and financial consequences that can be experienced by family members caring for dementia patients' $[6,7]$. Although there is evidence of positive aspects of informal caring [8-13], it is well documented that caring is associated with poor quality of life and deteriorating health for many caregivers, especially in cases where care is extremely demanding and long-term [8]. This nonsystematic review of the available literature aims to identify factors that contribute to caregiver burden and discusses interventions that may reduce the burden of caring for patients with $\mathrm{AD}$.

\section{Methods}

Search Strategy

A search of the online Medline (http://www.ncbi.nlm.nih.gov/pubmed) and Google Scholar literature databases was performed in January 2012 using combinations and synonyms of the following terms: Alzheimer's disease, caregiving, caregiver burden, interventions and support. Articles were limited to those published in the English language. No publication date limits were applied. The search results were then assessed for relevance using the publication titles and abstracts. Further relevant references were selected from the bibliographies of the identified papers. Eight of the key studies identified by the search are described in more detail in table 1.

\section{Results}

\section{Consequences of Caregiving}

When examining caregiver burden, both the positive and negative effects of caregiving should be taken into account. Although there is evidence for some positive effects of caregiving, negative effects on the physical, social, emotional and financial status of the AD caregiver can be devastating $[7,14]$. Moreover, it has been reported that some of these negative effects may persist for up to 12 months after caregiving ceases [15]. For these reasons, this review focuses predominantly on the negative effects of caregiving.

\section{Negative Effects of Caregiving}

Caregiving is associated with a range of psychological and physical symptoms [16-19] (fig. 1). Misunderstanding or lack of knowledge about the course of AD as well as beliefs about the moral duty of family members to provide care, possibly resulting in an unwilling- 
Beinart et al.: Caregiver Burden and Psychoeducational Interventions in

Table 1. Studies investigating interventional support for caregivers of patients with $\mathrm{AD}$

\begin{tabular}{|c|c|c|c|c|c|}
\hline $\begin{array}{l}\text { Ref- } \\
\text { erence }\end{array}$ & Interventions & Study design & Inclusion criteria & Results & Comments/conclusions \\
\hline $\begin{array}{l}\text { Brennan } \\
\text { et al., } \\
1995[51]\end{array}$ & $\begin{array}{l}\text { Computer-based } \\
\text { support as needed } \\
(\mathrm{n}=51) \text { vs. control } \\
(\mathrm{n}=51)\end{array}$ & $\begin{array}{l}\text { Randomised } \\
\text { controlled } \\
12 \text {-month study }\end{array}$ & $\begin{array}{l}\text { Caregiver: primary } \\
\text { caregiver, access to } \\
\text { telephone, able to } \\
\text { read and write in } \\
\text { English; } \\
\text { Patient: not specified }\end{array}$ & $\begin{array}{l}\text { Caregivers' decision-making } \\
\text { confidence was improved; } \\
\text { Caregivers' decision-making } \\
\text { skill was unaffected; } \\
\text { No changes in social isolation }\end{array}$ & $\begin{array}{l}\text { Improvements observed in } \\
\text { caregivers' decision-making } \\
\text { confidence alone }\end{array}$ \\
\hline $\begin{array}{l}\text { Mahoney } \\
\text { et al., } \\
2003[21]\end{array}$ & $\begin{array}{l}\text { Computer-mediated } \\
\text { automated } \\
\text { interactive voice } \\
\text { response }^{\mathrm{a}}(\mathrm{n}=49) \text { vs. } \\
\text { usual care }(\mathrm{n}=51)\end{array}$ & $\begin{array}{l}\text { Randomised } \\
\text { controlled study over } \\
\text { a period of } 18 \text { months } \\
\text { (12 months of } \\
\text { treatment and } 6 \\
\text { months of follow-up) }\end{array}$ & $\begin{array}{l}\text { Caregiver: } \geq 18 \text { years, } \\
\text { minimum of } 4 \text { h care } \\
\text { per day for } 6 \text { months } \\
\text { for patient with } \\
\text { impaired ADLs; } \\
\text { Patient: MMSE score } \\
\leq 23\end{array}$ & $\begin{array}{l}\text { Significant effect of } \\
\text { intervention for caregivers } \\
\text { with low mastery at baseline, } \\
\text { with decreases in the levels of } \\
\text { bother }(\mathrm{p}=0.04) \text {, anxiety ( } \mathrm{p}= \\
0.01) \text { and depression }(\mathrm{p}= \\
0.007) \text { vs. the control group }\end{array}$ & $\begin{array}{l}\text { Caregivers who exhibited } \\
\text { low mastery and high anxiety } \\
\text { at baseline benefited the most; } \\
\text { The authors concluded that, } \\
\text { to optimise outcome effects, } \\
\text { similar interventions should } \\
\text { be individualised to the } \\
\text { caregiver }\end{array}$ \\
\hline $\begin{array}{l}\text { Winter and } \\
\text { Gitlin, } \\
2006[50]\end{array}$ & $\begin{array}{l}\text { Tele-support linking } \\
5 \text { caregivers per } \\
\text { group for } 1 \mathrm{~h} / \text { week } \\
(\mathrm{n}=58) \text { vs. usual } \\
\text { care }(\mathrm{n}=45)\end{array}$ & $\begin{array}{l}\text { Randomised } \\
\text { controlled } \\
6 \text {-month study }\end{array}$ & $\begin{array}{l}\text { Caregivers: female, } \\
\geq 50 \text { years, providing } \\
\text { care for } \geq 6 \text { months, } \\
\text { weekly access to } \\
\text { telephone for } 1 \mathrm{~h} \text {; } \\
\text { Patient: physicians } \\
\text { diagnosis of AD or } \\
\text { related dementia }\end{array}$ & $\begin{array}{l}\text { Minimal benefits for tele- } \\
\text { support vs. usual care: } \\
\text { Aged 50-64 years: burden } \\
(\mathrm{p}=0.490) \text {, gain }(\mathrm{p}=0.932) \\
\text { depression }(\mathrm{p}=0.121) \\
\text { Aged } \geq 65 \text { years: burden } \\
(\mathrm{p}=0.352) \text {, gain }(\mathrm{p}=0.086) \\
\text { depression }(\mathrm{p}=0.014)\end{array}$ & $\begin{array}{l}\text { The authors concluded that } \\
\text { the benefits of tele-support } \\
\text { were minimal and only } \\
\text { observed in older female } \\
\text { caregivers (aged } \geq 65 \text { years) }\end{array}$ \\
\hline $\begin{array}{l}\text { Eisdorfer } \\
\text { et al., } \\
2003[55]\end{array}$ & $\begin{array}{l}\text { SET }(\mathrm{n}=75) \text { vs. SET } \\
\text { plus CTIS }(\mathrm{n}=77) \\
\text { vs. minimal support } \\
(\mathrm{n}=73)\end{array}$ & $\begin{array}{l}\text { Randomised } \\
\text { (stratified according } \\
\text { to ethnicity) } \\
\text { controlled 18-month } \\
\text { study (12 months of } \\
\text { treatment plus } 6 \\
\text { months of follow-up) }\end{array}$ & $\begin{array}{l}\text { Caregiver: cohabit } \\
\text { and provide } \\
\text { minimum of } 4 \mathrm{~h} \text { care } \\
\text { per day for prior } \\
6 \text { months; } \\
\text { Additional family } \\
\text { member: provide } \\
\text { emotional or } \\
\text { instrumental support; } \\
\text { Patient: MMSE score } \\
<24 \text { with impaired } \\
\text { ADLs }\end{array}$ & $\begin{array}{l}\text { Reduction in depression in } \\
\text { the SET plus CTIS group at } \\
6 \text { months, which differed } \\
\text { according to ethnicity } \\
\text { (Cuban American or White } \\
\text { American) and relationship to } \\
\text { patient }\end{array}$ & $\begin{array}{l}\text { Information technology has a } \\
\text { promising role in alleviating } \\
\text { distress and depression among } \\
\text { groups of AD caregivers; } \\
\text { Interventions have differential } \\
\text { impacts according to ethnic } \\
\text { group and the caregiver- } \\
\text { patient relationship }\end{array}$ \\
\hline $\begin{array}{l}\text { Mittelman } \\
\text { et al., } \\
2004[47]\end{array}$ & $\begin{array}{l}\text { Multicomponent, } \\
\text { individualised } \\
\text { counselling and } \\
\text { support }(\mathrm{n}=203) \text { vs. } \\
\text { usual care }(\mathrm{n}=203)\end{array}$ & $\begin{array}{l}\text { Randomised } \\
\text { controlled study } \\
\text { (results presented for } \\
\text { 4-year analysis) }\end{array}$ & $\begin{array}{l}\text { Caregiver: spouse of } \\
\text { patient with AD, } \\
\text { cohabiting, and } \\
\text { with primary } \\
\text { responsibility for care }\end{array}$ & $\begin{array}{l}\text { Rates of behaviour problems } \\
\text { increased over time and did } \\
\text { not differ with intervention } \\
\text { method; } \\
\text { Caregivers in the control } \\
\text { group appraised behaviour as } \\
\text { increasingly distressing over } \\
\text { the } 4 \text {-year period; } \\
\text { Caregivers in the treatment } \\
\text { group rated behaviour as less } \\
\text { and less distressing over the } \\
\text { same period }\end{array}$ & $\begin{array}{l}\text { The authors concluded that } \\
\text { psychosocial intervention can } \\
\text { provide caregivers with } \\
\text { strategies to help them } \\
\text { manage their reactions to } \\
\text { behaviour problems more } \\
\text { effectively }\end{array}$ \\
\hline $\begin{array}{l}\text { Martin- } \\
\text { Carrasco } \\
\text { et al., } \\
2009 \text { [45] }\end{array}$ & $\begin{array}{l}\text { PIP plus standard } \\
\text { care }(\mathrm{n}=60) \text { vs. } \\
\text { standard care alone } \\
(\mathrm{n}=55)\end{array}$ & $\begin{array}{l}\text { Multicentre } \\
\text { prospective } \\
\text { randomised } \\
\text { 10-month study ( } 4 \\
\text { months of treatment } \\
\text { plus } 6 \text { months of } \\
\text { follow-up) }\end{array}$ & $\begin{array}{l}\text { Caregiver: minimum } \\
\text { of } 4 \text { h per day for } \\
\text { patient with impaired } \\
\text { ADLs and baseline } \\
\text { Zarit score }>22 \text {; } \\
\text { Patient: MMSE score } \\
10-26 \text { and receiving } \\
\text { rivastigmine }(\geq 6 \mathrm{mg} / \\
\text { day) for prior } \\
6 \text { months }\end{array}$ & $\begin{array}{l}\text { Zarit scale: mean score } \\
\text { reduction in PIP group } \\
\text { greater than in control group } \\
(\mathrm{p}=0.0083) \text {; } \\
\mathrm{SF}-36 \text { : mean scores } \\
\text { significantly higher in PIP } \\
\text { than the control group in all } \\
\text { the dimensions }(\mathrm{p}<0.05) \\
\text { except for mental health }\end{array}$ & $\begin{array}{l}\text { Supports the efficacy of PIP in } \\
\text { reducing caregiver burden in } \\
\text { AD; } \\
\text { The reduction in burden } \\
\text { seems to improve the quality } \\
\text { of life in relation to health and } \\
\text { rates of psychiatric morbidity; } \\
\text { The positive effects of PIP } \\
\text { continued to last for at least a } \\
\text { further } 6 \text { months }\end{array}$ \\
\hline $\begin{array}{l}\text { Burns } \\
\text { et al., } \\
2003[46]\end{array}$ & $\begin{array}{l}\text { Training in } \\
\text { behaviour } \\
\text { management } \\
(\mathrm{n}=85) \text { vs. training } \\
\text { in behaviour } \\
\text { management plus } \\
\text { training to cope } \\
\text { with stress }(\mathrm{n}=82)\end{array}$ & $\begin{array}{l}\text { Randomised (with } \\
\text { stratification } \\
\text { according to race and } \\
\text { gender) 24-month } \\
\text { study }\end{array}$ & $\begin{array}{l}\text { Caregiver: }>21 \text { years, } \\
\text { minimum of } 4 \text { h care } \\
\text { per day for } \geq 6 \\
\text { months; } \\
\text { Patient: MMSE score } \\
<24\end{array}$ & $\begin{array}{l}\text { Behaviour management plus } \\
\text { coping skills improved } \\
\text { general well-being }(\mathrm{p}=0.004) \\
\text { and depression }(\mathrm{p}=0.007) \\
\text { over time }\end{array}$ & $\begin{array}{l}\text { The authors conclude that } \\
\text { brief primary care } \\
\text { interventions may be effective } \\
\text { in reducing caregiver distress } \\
\text { and burden in the long-term } \\
\text { management of AD patients; } \\
\text { Interventions that focus only } \\
\text { on care recipient behaviour, } \\
\text { without addressing care- } \\
\text { giving issues, may not be as } \\
\text { adequate for reducing } \\
\text { caregiver distress as combined } \\
\text { approaches }\end{array}$ \\
\hline
\end{tabular}


Table 1 (continued)

\begin{tabular}{|c|c|c|c|c|c|}
\hline $\begin{array}{l}\text { Ref- } \\
\text { erence }\end{array}$ & Interventions & Study design & Inclusion criteria & Results & Comments/conclusions \\
\hline $\begin{array}{l}\text { Mittelman } \\
\text { et al., } \\
2008 \text { [49] }\end{array}$ & $\begin{array}{l}\text { Individual and family } \\
\text { counselling with ad } \\
\text { hoc telephone } \\
\text { counselling plus } \\
\text { donepezil treatment } \\
\text { for patient }(\mathrm{n}=79) \\
\text { vs. donepezil alone } \\
(\mathrm{n}=79)\end{array}$ & $\begin{array}{l}\text { Randomised } \\
\text { controlled } 24 \text {-month } \\
\text { study (formalised } \\
\text { counselling for } 3 \\
\text { months followed by } \\
\text { ad hoc counselling } \\
\text { and follow-up for } 21 \\
\text { months) }\end{array}$ & $\begin{array}{l}\text { Caregiver: spouse of } \\
\text { patient with } \mathrm{AD}, \\
\text { cohabiting and self- } \\
\text { defined primary } \\
\text { caregiver; } \\
\text { Patient: probable } \mathrm{AD} \text {, } \\
\text { GDS score } 4-5\end{array}$ & $\begin{array}{l}\text { Caregiver depression was } \\
\text { significantly reduced at } 3 \\
\text { months in those who received } \\
\text { counselling compared with } \\
\text { those who did not; } \\
\text { The reduction in depression } \\
\text { persisted for the entire } 24 \\
\text { months of the study; } \\
\text { Depression scores for } \\
\text { caregivers who did not receive } \\
\text { counselling increased over the } \\
\text { study period }\end{array}$ & $\begin{array}{l}\text { Effective counselling and } \\
\text { support interventions can } \\
\text { reduce symptoms of } \\
\text { depression in caregivers; } \\
\text { The authors recommend } \\
\text { combining ChEIs and } \\
\text { supportive counselling for } \\
\text { patients with AD and their } \\
\text { caregivers }\end{array}$ \\
\hline
\end{tabular}

ADLs = Activities of daily living; CTIS = computer/telephone-integrated system (information system and tele-support); GDS = Global Deterioration Scale; MMSE $=$ Mini-Mental State Examination; $\mathrm{PIP}=$ psychoeducational interventional program; $\mathrm{SET}=$ structural ecosystems therapy $($ fam ily therapy intervention).

${ }^{a}$ Comprised caregiver stress monitoring and counselling information, personal voice mail linkage to AD experts, a voice mail telephone support group and a distraction call for care recipients.

${ }^{b}$ Standard care comprised individual 90-min sessions, at 1- to 2-week intervals over 4 months, providing general information about how AD progresses, individualised information about the patient, both in person and over the telephone 'on demand', information leaflets about AD and information about resources directed at caregivers available in their community.

ness or inability to ask for help and withdrawal from wider society to care for a relative, can drive caregivers into a downward spiral of isolation, loneliness and depression [20-22].

Among caregivers of the general older population, including people likely to have a diagnosis of AD, Aggar et al. [23] identified disrupted daily routine, health problems, financial strain and a lack of family support as important causes of depression and anxiety. Furthermore, there is an association between depression in caregivers and reduced physical wellbeing, such as disrupted sleep patterns, increased incidence of cardiovascular and metabolic diseases, lowered immunity and early transition to frailty syndrome [17]. Some studies have reported that $\mathrm{AD}$ caregivers are at risk of depression [24,25], with prevalence rates of selfreported depression among community-dwelling caregivers reported to be as high as $83 \%$ [25]. In a recent study, the caregivers' poor perceived health was associated with emotional exhaustion, depression, anxiety and increased levels of burden [26].

\section{Positive Effects of Caregiving}

Although most research has focused on the negative aspects of informal caregiving, there is also evidence of caregiver gain in AD. Positive caregiving outcomes reported include companionship, reward and enjoyment [8-13]. Among AD caregivers, personal factors associated with a positive caregiving experience include a good previous relationship with the patient, older age, good health, maintenance of leisure time, less venting of emotions, being the caregiver through their own choice and satisfaction with social support [8-13,27].

\section{Factors Contributing to Caregiver Burden}

The level of burden experienced by the caregiver of a patient with AD depends upon both caregiver and patient factors [28] (fig. 2). It should be noted that the extent to which some of these factors are a consequence, or a cause, of caregiver burden is not always clear. For example, caregiver depression may increase caregiver burden, or may be a result of it.

\section{Caregiver Attributes Affecting Caregiver Burden}

Demographic and psychosocial attributes of the caregiver that predict greater burden include older age, lower socioeconomic status, family relationship, type of coping strategy and poor access to/low acceptance of social support [17]. The effect of gender is interesting, with a number of studies indicating that male caregivers are more susceptible to physical ill- 
Fig. 1. The negative effects of caregiving in $\mathrm{AD}$.

Fig. 2. Patient and caregiver attributes related to caregiver burden in AD.
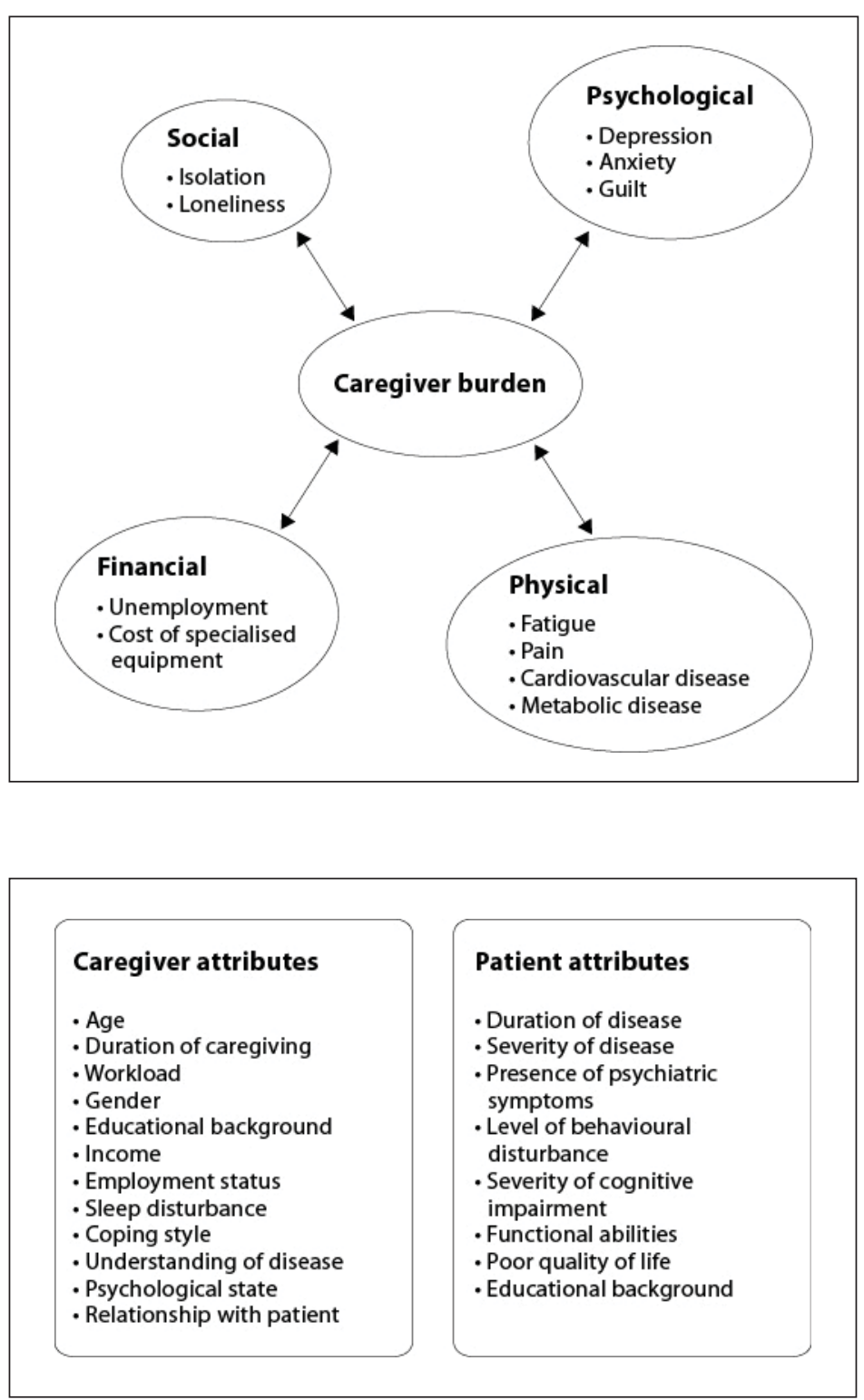

nesses (such as cardiovascular disease) as a result of caregiving. Female caregivers have been found to be at higher risk of psychological symptoms (such as loneliness and depression) when compared with male caregivers [22, 28, 29].

The type of coping strategy is an important predictor of caregiver burden [30]. For example, caregivers who use wishful thinking and stoicism as coping strategies report a greater level of burden than those who confront problems and seek information and social support for dealing with them. A systematic review of 35 studies suggested that the most successful approach to deal with caring for a patient with AD combines emotion-based coping (accepting what cannot be changed) with problem-focused coping (considering the advantages and disadvantages and finding alternative solutions), covering the full range of coping strategies [30]. Furthermore, AD caregivers who believe they have more control over their caring role and those who accept challenges in life are less likely to suffer from depression than their counterparts [31]. 
Interestingly, adult children of patients with $\mathrm{AD}$ appear to be less adversely affected by caring for a parent than spousal caregivers [6]. Thus, within caregiving families, one's relationship to the care recipient is an important consideration [21].

Patient Attributes Affecting Caregiver Burden

Among the attributes of the patient, the most significant predictors of caregiver burden are reported to be the level of the patient's behavioural disturbance and cognitive function $[16,17,19,28,32]$. For example, disruptive behaviours, such as wandering and verbal assault, common in middle-stage $\mathrm{AD}$, are frequently reported by caregivers as the primary cause of their burdensome feelings [21, 33, 34]. In a study involving 421 ambulatory AD patients with agitation or psychosis, increased severity of a patient's psychiatric and behavioural symptoms had a greater impact on caregiver burden than the patient's sociodemographic characteristics, functional abilities or intensity of care needed [19]. In addition to these specific $\mathrm{AD}$-related symptoms and behaviours, caregiver burden in $\mathrm{AD}$ is also strongly associated with the duration of dementia, the educational level of the patient and the presence of depression in the patient $[17,19,35]$.

As $\mathrm{AD}$ progresses, caregivers face increasing problems with administering medications [36], and, unsurprisingly, increased caregiver burden is associated with patient resistance to treatment $[37,38]$. Interestingly, a number of studies have reported that caregivers are more satisfied when treatment administration is easier - for example, if the dosing schedule is simpler or the treatment takes less time and effort to administer. Indeed, evidence suggests that transdermal drug delivery is preferred over oral delivery, with the potential for increased adherence with this mode of administration [39-42].

\section{Interventions to Support Caregivers of Patients with AD}

As the burden of caregiving in $\mathrm{AD}$ can lead to both physical and psychological illnesses in caregivers, it is essential to ensure that caregiver well-being is maintained as the patient's disease progresses $[18,43]$. Numerous studies have investigated interventions designed to support caregivers of patients with $\mathrm{AD}$. Both face-to-face and telehealth interventions are discussed below. These are summarised in more detail in table 1 .

Face-to-Face Interventions

Selwood et al.'s [44] systematic review of short- and long-term psychological interventions for caregivers suggested that teaching caregivers coping strategies is an effective method for relieving caregiver burden and that one-to-one teaching is more effective than group sessions. The authors found no evidence for the efficacy of interventions solely containing an educational component, group behavioural therapy or supportive therapy [44].

Face-to-face interventions that have been most successful are based on psychosocial training together with educational sessions. These interventions cover a number of different areas, including information about the disease, the organisation of care, practical advice for coping with $\mathrm{AD}$, skills training for handling the behavioural problems of the patient, teaching decision-making skills, advice about the emotional repercussions of being a caregiver and advice about self-care [45-48].

Psychosocial interventions (including ad hoc tele-support) for caregivers in combination with cholinesterase inhibitor therapy for the patient have also proved successful for reducing caregiver depression [49]. Combined drug and psychosocial approaches in the management of patients with $\mathrm{AD}$ may be more effective in reducing caregiver burden, though further studies are warranted [49]. 
Beinart et al.: Caregiver Burden and Psychoeducational Interventions in

Alzheimer's Disease: A Review

Telephone-Based Support Programmes

Telephone- or computer-based support programmes could be practical low-cost interventions for reducing caregiver burden in some situations. For example, in a study investigating an automated telephone support system for caregiving spouses of patients with disruptive behaviour, tele-support showed significant benefits when compared with a usual care control group [21]. Furthermore, spouses with low mastery and high anxiety scores at baseline derived the greatest benefit from this approach. In a separate study, groups of up to five caregivers were invited to take part in interlinked tele-support sessions facilitated by a social worker. Over the 6-month study period, the average session uptake was 14.6 out of 26 possible sessions, and caregivers aged $\geq 65$ years reported fewer symptoms of depression than those in a control group. However, younger caregivers did not benefit from this approach [50].

\section{Computer-Based Support Systems}

Brennan et al. [51] investigated the effects of computer systems to provide information, decision-making support and communication to AD caregivers. Although they reported increased confidence in decision-making (a primary outcome) in the caregivers, there were no significant improvements in decision-making skills or social isolation. However, the researchers found that there was a wide variation in access to, and actual use of, the computerised intervention, which may have affected the overall results. Further investigations in this area may be of value, considering recent developments in computer technology.

\section{Discussion}

This review represents a comprehensive summary of the most recent literature on the burden of caring for AD patients, the factors that affect the level of burden and the types of intervention that have been shown to reduce burden. Caregiving is associated with a range of negative psychological and physical symptoms as well as financial strains and social isolation. In combination, these symptoms can lead to a high level of burden for the caregiver. Factors that can influence the level of burden for an individual can be categorised into caregiver attributes, such as age, socioeconomic status and coping strategy, and patient attributes, such as the level of behavioural disturbance and cognitive function. The literature suggests that interventions that are individually tailored to a caregiver are particularly effective at reducing this caregiver's burden and should be further investigated [17, 44, 52]. It is paramount that health-care professionals are instrumental in providing help for caregivers of patients with $\mathrm{AD}$ and should aim to provide the means for caregiver education about dementia, psychological support and assistance in mobilising social support networks [53].

This evidence from studies investigating interventions for caregivers of AD patients, along with information from studies where a positive effect of caregiving has been documented, should be applied to future strategies aiming to decrease the burden of caregivers of individuals with $\mathrm{AD}$ (table 2). As such, there is a need for individualised educational and support programmes to teach caregivers positive coping techniques, together with ways to aid management of their care recipients with $\mathrm{AD}$. Furthermore, the use of effective pharmacological treatment for the improvement and/or stabilisation of AD symptoms in the patient is also likely to improve caregiver burden.

The findings of this review have some limitations that should be noted. Data on certain types of interventions, such as computer-based support, are limited and could be considered out-of-date in view of recent advances in computer technology. Furthermore, comparisons between studies can be difficult due to the variety of tools used for assessment and differences in study design. Systematic reviews have shown that few studies investigating care- 
Table 2. Recommendations for interventional support for caregivers of patients with AD

Caregiver education

Coping techniques

Managing patient's behaviour

Support from health-care workers

Frequent interaction with caregiver

Availability for ad hoc sessions
Interaction with patient

Participation in enjoyable activities

Medication

Easy route of administration

giver interventions in $\mathrm{AD}$ meet rigorous quality standards [44, 52, 54]. Thus, cross-study comparisons of caregiver burden in $\mathrm{AD}$ can be difficult given the number of assessments used. Frequently, measurement scales provide a total score and do not distinguish between different dimensions such as the condition of the patient, care requirements or the strain experienced by the caregiver or family [7]. Burden is a multidimensional construct, and a global score is unlikely to provide a complete and accurate assessment.

\section{Conclusions}

Caregiving in $\mathrm{AD}$ is associated with poor quality of life and deteriorating health for both the caregiver and the care recipient. Both caregiver and patient attributes contribute to the level of caregiver burden. Many studies have demonstrated benefits for strategies designed to relieve caregiver burden in AD; however, a lack of standardisation in study design, assessment of different outcomes and the use of a variety of different measurement tools make it difficult to judge which are the most effective. The available evidence suggests that caregiver support should enhance the positive aspects of their role as well as addressing problems arising from caregiving. Consequently, interventions should be tailored to the individual situation and aim to maintain mental well-being, encourage participation in educational and support programmes, and teach appropriate coping and dementia-specific management strategies. Strategies combining drug therapy for the patient and psychosocial approaches for the caregiver may be effective in reducing caregiver burden and should be investigated further. Additionally, the reporting of caregiver burden as a variable in clinical study designs for AD medications would focus attention on this current concern and enable the collection of data that can further characterise the humanistic and economic burden of disease. In turn, these data may be useful in the assessment of the relative effectiveness of interventions.

\section{Acknowledgment}

Editorial assistance for this paper was provided by Fishawack Communications; this was funded by Novartis Pharma AG.

\section{Disclosure Statement}

R. Brady is an employee of Atlantis Healthcare and D. Wade is a previous employee of Atlantis Healthcare. N. Beinart and J. Weinman act as consultants for Atlantis Healthcare. Atlantis Healthcare was commissioned by Novartis Pharma AG to develop a carer support program for patients prescribed the rivastigmine patch. 


\section{References}

1 Reitz C, Brayne C, Mayeux R: Epidemiology of Alzheimer disease. Nat Rev Neurol 2011;7:137-152.

-2 Ballard C, Gauthier S, Corbett A, Brayne C, Aarsland D, Jones E: Alzheimer's disease. Lancet 2011; 377:1019-1031.

-3 Ferri CP, Prince M, Brayne C, Brodaty H, Fratiglioni L, Ganguli M, Hall K, Hasegawa K, Hendrie H, Huang Y, Jorm A, Mathers C, Menezes PR, Rimmer E, Scazufca M: Global prevalence of dementia: A Delphi consensus study. Lancet 2005;366:2112-2117.

4 Luengo-Fernandez R, Leal J, Gray A: Dementia 2010. The economic burden of dementia and associated research funding in the United Kingdom, 2010. http://www.dementia2010.org/reports/ Dementia2010Full.pdf (accessed July 2012).

5 Alzheimer's Association; Thies W, Bleiler L: 2011 Alzheimer's disease facts and figures. Alzheimers Dement 2011;7:208-244.

-6 George LK, Gwyther LP: Caregiver well-being: A multidimensional examination of family caregivers of demented adults. Gerontologist 1986;26:253-259.

-7 Ankri J, Andrieu S, Beaufils B, Grand A, Henrard JC: Beyond the global score of the Zarit Burden Interview: useful dimensions for clinicians. Int J Geriatr Psychiatry 2005;20:254-260.

-8 Beach SR, Schulz R, Yee JL, Jackson S: Negative and positive health effects of caring for a disabled spouse: longitudinal findings from the caregiver health effects study. Psychol Aging 2000;15:259271.

-9 Cohen CA, Colantonio A, Vernich L: Positive aspects of caregiving: rounding out the caregiver experience. Int J Geriatr Psychiatry 2002;17:184-188.

10 Searson R, Hendry AM, Ramachandran R, Burns A, Purandare N: Activities enjoyed by patients with dementia together with their spouses and psychological morbidity in carers. Aging Ment Health 2008; 12:276-282.

-11 Liew TM, Luo N, Ng WY, Chionh HL, Goh J, Yap P: Predicting gains in dementia caregiving. Dement Geriatr Cogn Disord 2010;29:115-122.

-12 Roff LL, Burgio LD, Gitlin L, Nichols L, Chaplin W, Hardin JM: Positive aspects of Alzheimer's caregiving: the role of race. J Gerontol B Psychol Sci Soc Sci 2004;59:P185-P190.

-13 Lopez J, Lopez-Arrieta J, Crespo M: Factors associated with the positive impact of caring for elderly and dependent relatives. Arch Gerontol Geriatr 2005;41:81-94.

-14 Vellone E, Piras G, Talucci C, Cohen MZ: Quality of life for caregivers of people with Alzheimer's disease. J Adv Nurs 2008;61:222-231.

-15 Grant I, Adler KA, Patterson TL, Dimsdale JE, Ziegler MG, Irwin MR: Health consequences of Alzheimer's caregiving transitions: effects of placement and bereavement. Psychosom Med 2002;64: 477-486.

-16 Clyburn LD, Stones MJ, Hadjistavropoulos T, Tuokko H: Predicting caregiver burden and depression in Alzheimer's disease. J Gerontol B Psychol Sci Soc Sci 2000;55:S2-S13.

-17 Pinquart M, Sorensen S: Correlates of physical health of informal caregivers: a meta-analysis. J Gerontol B Psychol Sci Soc Sci 2007;62:P126-P137.

-18 Mills PJ, Ancoli-Israel S, von Kanel R, Mausbach BT, Aschbacher K, Patterson TL, Ziegler MG, Dimsdale JE, Grant I: Effects of gender and dementia severity on Alzheimer's disease caregivers' sleep and biomarkers of coagulation and inflammation. Brain Behav Immun 2009;23:605-610.

- 19 Mohamed S, Rosenheck R, Lyketsos CG, Schneider LS: Caregiver burden in Alzheimer disease: cross-sectional and longitudinal patient correlates. Am J Geriatr Psychiatry 2010;18:917-927.

-20 Gruffydd E, Randle J: Alzheimer's disease and the psychosocial burden for caregivers. Community Pract 2006;79:15-18.

-21 Mahoney DF, Tarlow BJ, Jones RN: Effects of an automated telephone support system on caregiver burden and anxiety: findings from the REACH for TLC intervention study. Gerontologist 2003;43: $556-567$.

-22 Beeson R, Horton-Deutsch S, Farran C, Neundorfer M: Loneliness and depression in caregivers of persons with Alzheimer's disease or related disorders. Issues Ment Health Nurs 2000;21:779-806.

-23 Aggar C, Ronaldson S, Cameron ID: Reactions to caregiving of frail, older persons predict depression. Int J Ment Health Nurs 2010;19:409-415.

-24 Varela G, Varona L, Anderson K, Sansoni J: Alzheimer's care at home: a focus on caregivers strain. Prof Inferm 2011;64:113-117. 
-25 Drinka TJ, Smith JC, Drinka PJ: Correlates of depression and burden for informal caregivers of patients in a geriatrics referral clinic. J Am Geriatr Soc 1987;35:522-525.

- 26 Valente LE, Truzzi A, Souza WF, Alves GS, Alves CE, Sudo FK, Lanna ME, Moreira DM, Engelhardt E, Laks J: Health self-perception by dementia family caregivers: sociodemographic and clinical factors. Arq Neuropsiquiatr 2011;69:739-744.

-27 Cohen CA, Gold DP, Shulman KI, Zucchero CA: Positive aspects in care-giving: an overlooked variable in research. Can J Aging 1994;13:378-391.

- 28 Schölzel-Dorenbos CJ, Draskovic I, Vernooij-Dassen MJ, Olde Rikkert MG: Quality of life and burden of spouses of Alzheimer disease patients. Alzheimer Dis Assoc Disord 2009;23:171-177.

-29 Pinquart M, Sorensen S: Helping caregivers of persons with dementia: which interventions work and how large are their effects? Int Psychogeriatr 2006;18:577-595.

-30 Li R, Cooper C, Bradley J, Shulman A, Livingston G: Coping strategies and psychological morbidity in family carers of people with dementia: a systematic review and meta-analysis. J Affect Disord 2012; 139:1-11.

-31 O’Rourke N, Kupferschmidt AL, Claxton A, Smith JZ, Chappell N, Beattie BL: Psychological resilience predicts depressive symptoms among spouses of persons with Alzheimer disease over time. Aging Ment Health 2010;14:984-993.

- 32 Germain S, Adam S, Olivier C, Cash H, Ousset PJ, Andrieu S, Vellas B, Meulemans T, Reynish E, Salmon E: Does cognitive impairment influence burden in caregivers of patients with Alzheimer's disease? J Alzheimers Dis 2009;17:105-114.

- 33 Gaugler JE, Wall MM, Kane RL, Menk JS, Sarsour K, Johnston JA, Beusching D, Newcomer R: The effects of incident and persistent behavioral problems on change in caregiver burden and nursing home admission of persons with dementia. Med Care 2010;48:875-883.

-34 Gaugler JE, Wall MM, Kane RL, Menk JS, Sarsour K, Johnston JA, Schuh K, Newcomer R: Does caregiver burden mediate the effects of behavioral disturbances on nursing home admission? Am J Geriatr Psychiatry 2011;19:497-506.

-35 Garcia-Alberca JM, Lara JP, Berthier ML: Anxiety and depression in caregivers are associated with patient and caregiver characteristics in Alzheimer's disease. Int J Psychiatry Med 2011;41:57-69.

-36 Bassil N, Thaipisuttikul P, Grossberg GT: Memantine ER, a once-daily formulation for the treatment of Alzheimer's disease. Expert Opin Pharmacother 2010;11:1765-1771.

-37 Small G, Dubois B: A review of compliance to treatment in Alzheimer's disease: potential benefits of a transdermal patch. Curr Med Res Opin 2007;23:2705-2713.

- 38 Lingler JH, Martire LM, Schulz R: Caregiver-specific outcomes in antidementia clinical drug trials: a systematic review and meta-analysis. J Am Geriatr Soc 2005;53:983-990.

-39 Sevilla C, Jimenez Caballero PE, Alfonso V, Gonzalez-Adalid M: Current treatments of Alzheimer disease: are main caregivers satisfied with the drug treatments received by their patients? Dement Geriatr Cogn Disord 2009;28:196-205.

-40 Blesa R, Ballard C, Orgogozo JM, Lane R, Thomas SK: Caregiver preference for rivastigmine patches versus capsules for the treatment of Alzheimer disease. Neurology 2007;69:S23-S28.

-41 Winblad B, Kawata AK, Beusterien KM, Thomas SK, Wimo A, Lane R, Fillit H, Blesa R: Caregiver preference for rivastigmine patch relative to capsules for treatment of probable Alzheimer's disease. Int J Geriatr Psychiatry 2007;22:485-491.

-42 Abetz L, Rofail D, Mertzanis P, Heelis R, Rosa K, Tellefsen C, Roborel de Climens A, McBurney C, Thomas S: Alzheimer's disease treatment: assessing caregiver preferences for mode of treatment delivery. Adv Ther 2009;26:627-644.

-43 Hayslip B, GiBaeg H, Anderson C: Predictors of Alzheimer's disease caregiver depression and burden: what non-care-giving adults can learn from active caregivers. Educ Gerontol 2008;34:945-969.

- 44 Selwood A, Johnston K, Katona C, Lyketsos C, Livingston G: Systematic review of the effect of psychological interventions on family caregivers of people with dementia. J Affect Disord 2007;101: 75-89.

-45 Martin-Carrasco M, Martin MF, Valero CP, Millan PR, Garcia CI, Montalban SR, Vazquez AL, Piris SP, Vilanova MB: Effectiveness of a psychoeducational intervention program in the reduction of caregiver burden in Alzheimer's disease patients' caregivers. Int J Geriatr Psychiatry 2009;24:489499.

-46 Burns R, Nichols LO, Martindale-Adams J, Graney MJ, Lummus A: Primary care interventions for dementia caregivers: 2-year outcomes from the REACH study. Gerontologist 2003;43:547-555. 
-47 Mittelman MS, Roth DL, Coon DW, Haley WE: Sustained benefit of supportive intervention for depressive symptoms in caregivers of patients with Alzheimer's disease. Am J Psychiatry 2004;161: 850-856.

-48 Martin-Carrasco M, Otermin P, Perez-Camo V, Pujol J, Aguera L, Martin MJ, Gobartt AL, Pons S, Balana M: EDUCA study: psychometric properties of the Spanish version of the Zarit Caregiver Burden Scale. Aging Ment Health 2010;14:705-711.

-49 Mittelman MS, Brodaty H, Wallen AS, Burns A: A three-country randomized controlled trial of a psychosocial intervention for caregivers combined with pharmacological treatment for patients with Alzheimer disease: effects on caregiver depression. Am J Geriatr Psychiatry 2008;16:893-904.

-50 Winter L, Gitlin LN: Evaluation of a telephone-based support group intervention for female caregivers of community-dwelling individuals with dementia. Am J Alzheimers Dis Other Demen 2006;21: 391-397.

-51 Brennan PF, Moore SM, Smyth KA: The effects of a special computer network on caregivers of persons with Alzheimer's disease. Nurs Res 1995;44:166-172.

-52 Olazaran J, Reisberg B, Clare L, Cruz I, Pena-Casanova J, Del Ser T, Woods B, Beck C, Auer S, Lai C, Spector A, Fazio S, Bond J, Kivipelto M, Brodaty H, Rojo JM, Collins H, Teri L, Mittelman M, Orrell M, Feldman HH, Muniz R: Nonpharmacological therapies in Alzheimer's disease: a systematic review of efficacy. Dement Geriatr Cogn Disord 2010;30:161-178.

53 Cohen CA, Pringle D, LeDuc L: Dementia caregiving: the role of the primary care physician. Can J Neurol Sci 2001;28(suppl 1):S72-S76.

- 54 Wisniewski SR, Belle SH, Coon DW, Marcus SM, Ory MG, Burgio LD, Burns R, Schulz R: The Resources for Enhancing Alzheimer's Caregiver Health (REACH): project design and baseline characteristics. Psychol Aging 2003;18:375-384.

-55 Eisdorfer C, Czaja SJ, Loewenstein DA, Rubert MP, Arguelles S, Mitrani VB, Szapocznik J: The effect of a family therapy and technology-based intervention on caregiver depression. Gerontologist 2003; 43:521-531. 